\title{
PALATALIZATION OF THE GLIDE IN FRISIAN RAISING DIPHTHONGS AS A CASE OF SHIFT ${ }^{1}$
}

\author{
Siebren Dyk \\ Fryske Akademy
}

\begin{abstract}
In Modern West Frisian, by New Frisian Breaking, two rising diphthongs have developed with initial/w/. However, in the eastern part of the language area these sequences are nowadays pronounced as [jo] and [ja], respectively. The change started when immigrant peat diggers became integrated into Frisian society, and as a result of imperfect learning did not master fully those difficult Frisian diphthongs. As an escape strategy, they fronted the initial glide to $/ \mathrm{j} /$. A second centre of hange was at the language border, where peat-digging also resulted in the mixing of populations. In the course of the 20th century, the new forms were rapidly spreading. An analysis of the change as a case of shift (cf. Thomason and Kaufman 1988) can nicely explain the platalization of the glide, and moreover, it gives insight into the question why this only occurred after labials. In the case of a minority-majority contact situation, however, change by shift in the minority language is not to be expected in the first place, as it requires that a population is switching to a target language that is less powerful or prestigeous. However, the peat diggers all spoke a Dutch Low Saxon dialect, which had a low prestige, indeed.
\end{abstract}

Keywords: Frisian, breaking, palatalisation, language shift, language prestige

\section{Introduction}

Since Thomason and Kaufman (1988) the phenomena in the area of contact-induced change are divided yn borrowing en shift. In the Frisian-Dutch contact situation, borrowing, to be characterized as primarily lexical en occurring over a long stretch of time, is a well-known cause of linguistic change in Frisian. This

This paper is a heavily abridged version of Dyk (2008), which was written in Frisian. Again, I thank Arjen Versloot and Willem Visser for their comments on a previous draft of that article. 
could be expected, since the balance of power and prestige between the languages is such indeed that Dutch is the majority language, and Frisian is the minority language. Borrowing from Dutch already occurs for centuries, and not only because Frisian did not have a word for a new concept.

In the frisistic literature, the pattern shift has also been discussed. Thus, in this way Frisian relics in dialects spoken in former Frisian areas have been explained. However, these cases of shift boil down at a movement away from Frisian. All this is understandable in a social context in which Frisian is the less powerfull partner. Original speakers of Frisian shifted towards a language that had more power and prestige at the time.

Nevertheless, in studying a certain phonological change within Frisian, I discovered that this can best be described in terms of shift. In other words, we have a case here where non-Frisians stood at the basis of a change within Frisian as a result of imperfect learning. So, this is a case of a movement is towards Frisian. Here, Frisian is the target language, and not the source language as in the aforementioned cases of shift, where we had a situation in which Frisians tried to master (a variety of) Dutch. This role of Frisian as a target language in the scenario of shift looks strange, as Frisian is always considered to be the least powerful party in the constellation of Dutch-Frisian language contact. In this paper, I would like to explain why such a change nevertheless could happen. But let us first go to the facts.

\section{A phonological change}

In the international linguistic literature, Modern Frisian Breaking is probably the phenomenon in the Frisian language that attracted the most attention.

Modern Frisian Breaking

$$
\begin{aligned}
& \text { I. } \partial>\mathrm{j} \varepsilon \\
& \mathrm{i} . \varepsilon>\mathrm{jI} \\
& \text { o. } \partial>\text { wa } \\
& \text { u. } \partial>\text { wo }
\end{aligned}
$$


Some examples of breaking are: ${ }^{2}$

bjemmen 'trees'; plural form of beam, German 'Baum'

stjintsje diminutive of stien 'stone'

bwadskip 'message', German 'Botschaft', from boade 'messager'

fwotbal 'football', compound of foet 'foot' and bal 'ball'

There is an aspect of Modern Frisian Breaking that has not got much attention in the literature, however. In the eastern part of Friesland, it happens that the raising diphthongs beginning with the back glide, viz. [w], underwent a further change, in that the back glide turned into the front glide [j]. So, the net result is that all raising diphthongs begin with $/ \mathrm{j} /$. Here are some examples:

$\begin{array}{llll}\text { bwartsje } & > & \text { bjartsje } & \text { 'to play' } \\ \text { bworrel } & > & \text { bjorrel } & \text { 'drink' (i.e. the noun) } \\ \text { pwarte } & > & \text { pjarte } & \text { 'gate' } \\ \text { pwollen } & > & \text { pjollen } & \text { 'pools' (plural of poel) } \\ \text { mwanne } & > & \text { mjanne } & \text { 'moon'; 'month' } \\ \text { mworre } & > & \text { mjorre } & \text { 'wall' (German: 'Mauer') } \\ \text { fwar } & > & \text { fjar } & \text { 'for' } \\ \text { fwotten } & > & \text { fjotten } & \text { 'feet' (plural of } \text { foet) }\end{array}$

The condition thus is, that the change occurs after bilabials $(b, p$, $m$ ) and after the labiodental $(f)$. In accordance to the latter is also, that we see the phenomenon in words that etymologically begin with a $\langle w\rangle$, which in Frisian is normally pronounced as a labiodental approximant $[v]$ :

$\begin{array}{llll}\text { nwartel } & > & \text { njattel } & \text { 'carrot'; 'root' (German: 'Wurzel') } \\ \text { nwarst } & > & \text { njast } & \text { 'sausage' (German: 'Wurst') }\end{array}$

In addition, we see the same pattern in the case where the original word etymologically had an initial vowel. Here, it must be assumed that a $/ \mathrm{n} /$ is inserted (cf. Fokkema 1966).

$$
\begin{array}{lll}
\text { wargel }> & \text { vjargel } & \text { 'organ' } \\
\text { waljekoek }> & \text { vjaljekoek } & \text { 'dough-nut' (from oalje 'oil') }
\end{array}
$$

2 In the notation of the examples, for exposatory reasons I stick to those phonetic properties that are essential for the problem at hand. For the same reason I do not use the Frisian orthography, which reflects the effects of breaking very poorly. 
Words with an etymological initial $/ \mathrm{h} /$ join these words with an initial vowel. When the vowel was broken, $/ \mathrm{h} /$ happened to stand in front of a glide, viz. w. However, in Frisian /h/ can only occur before full vowels. As a consequence, $/ \mathrm{h} /$ was deleted, for instance in the pronunciation of hoanne [wand] (from Old Frisian hona). Before [wand] there was inserted a labiodental [v] again, and this resulted in Eastern Frisian forms like:

$\begin{array}{llll}\text { wanne } & > & \text { vjanne } & \text { 'cock' (German: 'Hahn') } \\ \text { wastje } & > & \text { vjastje } & \text { 'to cough' (German: 'husten') }\end{array}$

We can conclude, then, that the change was restricted to the position after bilabials and labiodentals. Henceforth, I will subsume these categories under the term "labials". And indeed, after dentals or velars the change does not occur. One does not hear pronunciations like *djarp 'village' or *kjart 'short' in eastern Friesland.

Now that we have sketched what the change is about, three questions immediately manifest theirselves:

(i) Why should there be a change at all, and why is the change towards $/ \mathrm{j} /$ ?

(ii) Why is the change restricted to the position after labials?

(iii) Why did the change occur in eastern Friesland, and not in the whole language area at the same time?

\section{Why change at all?}

As to the question why there has been changed, the answer is probably pretty obvious: the raising diphthongs with $/ \mathrm{w} /$ are hard to master, especially since $[\mathrm{w}]$ has a weak position within the Frisian sound system, when we compare it to its sister glide /j/. Indications can be destilled from the literature, from various authors. For instance from first language acquisition:

"In the beginning, Frisian children say for boátsje 'to play', buórren 'neighbours', (...) mostly bátsje, borren, etc., and after that sometimes for a while bjátsje, bjorren, etc., and only after that the right form. The infant pronunciation is 
lasting longer, the more the children are under non-Frisian influence" (Hof 1933: 10) ${ }^{3}$

"It is remarkable that children who not master yet the phoneme combinations $\hat{u} a$, as in boartsje 'to play', replace the $\hat{u}$ by $j$ " (Fokkema 1940: 143)

"I know from personal recollection that sometimes small children use such and other similar forms as well, even outside the present-day [j] area. Usually such "mispronunciations" disappear due to the corrective influence of adult speakers" (Van der Meer 1985: 47)

But the behaviour is not only reported from first, but also from second language acquisition:

"When in the small town of Franeker, far from the palatalization area, children from non-Frisian-speaking families have to read Frisian at school, they also say "bjatsje" instead of "boartsje" (Boelens 1958: 154)

And in a magazine I found a rather funny description of a Frisian play which was performed for a society of Frisian emigrants in a town in the western part of the Netherlands. Just before she has to enter the stage, the director tries to stimulate an actress that is a native speaker of one of the dialects of Town Frisian. She had to say only one clause, but yet she had difficulties with its pronunciation:

- "Yes, you can tell me something, but I certainly get confused with that difficult word; how actually should it be: barne, no, bjarne, borne ..."

- "Boarne!"

3 (In Dutch:) "Friesche kinderen zeggen voor boátsje, spelen, buórren, buren, (...) aanvankelijk meest bátsje, borren, enz., en vervolgens soms nog een tijdlang bjátsje, bjorren, enz., en pas daarna het rechte. De kinderuitspraak duurt te langer, naarmate de kinderen meer onder onfrieschen invloed staan."

4 (In Dutch:) "Merkwaardig is dat kinderen die de phoneemverbindingen $\hat{u} a$ bijv. in boartsje "spelen" nog niet meester zijn de $\hat{u}$ vervangen door $j$ "

5 (In Dutch:) "Als in het stadje Franeker, dat ver buiten het mouilleringsgebied ligt, kinderen uit niet-Friessprekende gezinnen op school Fries moeten lezen, zeggen ze ook "bjatsje" voor "boartsje". 
- "Yes, right: bjarne, hopefully I won't forget that, you see. The calves bjarne ... right!"

$([\text { Hof }] 1903)^{6}$

The answer to the question why the change is towards $/ \mathrm{j} /$ is straightforward. The initial $/ \mathrm{w} /$ is a glide and is part of a raising diphthong. When there is a ban on /w/, and when one wants to maintain a raising diphthong, the shortest escape route is to turn to that other glide that can be part of a raising dipthong. That glide is $/ \mathrm{j} /$.

\section{Why change only after labials?}

It was stated above that pronunciation of the bilabial glide /w/ seems to be difficult. This was claimed for first and second language learners, but in fact the situation was not different for the ordinary language users. When they did not want to stick to this sound any longer, there was in fact a better alternative than switching to the other glide $/ \mathrm{j} /$. That was to the labiodental approximant / $/$. According to Cohen et al (1961), in Frisian the bilabial pronunciation was once the normal one when the phoneme on its own occupied the onset of a syllable, ${ }^{7}$ as is still the case in its historical sister English. In the course of history, this situation must have been changed, so that the translation of English wind is now pronounced as [nin] in Frisian. After a consonant, for instance in words like twa 'two', kwea 'evil' or swier 'heavy' (German: 'schwer'), Cohen et al state that nowadays some ("sommigen") also realize the approximantal pronunciation. In fact, this is an understatement. In the dialect atlas of Boelens and Van der Woude (1955), the pronunciation with $\mathrm{n}$ is certainly not in the minority, and the pronunciation with $\mathrm{n}$ even increased in the recent FAND-atlas. ${ }^{8}$ In fact, already Siebs (1901: 1251) observed this switch in the pronunciation.

6 (In Town Frisian and Frisian:) - "Ja, jo kenne wel wat segge, maar met dat slimme woard kom ik grif in 'e war; hoe is 't oek hast wear: barne, né bjarne, borne ..." - "Boarne!" - "Ja krekt: bjarne, a'k dat nou maer niet wear kwyt raek foartyd, sien je! De kealen bjarne ... krekt!"

7 In the onset, it can also occur for $r$, with the same development.

8 The Frisian part of the Fonologische Atlas van Nederlandse Dialecten has not been published yet. I thank Arjen Versloot for providing me with the data. 
Returning to the words involved in New Frisian Breaking, we also see that its products tend to be subject to this transition towards a pronunciation with the approximant $n$. For instance, this occurs in:

\begin{tabular}{|c|c|c|c|}
\hline [kwat] & $>$ & [kvat] & koart 'short' \\
\hline [gwon] & $>$ & [gvon] & guon 'some' \\
\hline [dwarp] & $>$ & [dvarp] & doarp 'village' (German: 'Dorf') \\
\hline [twar] & $>$ & [tvar] & toar 'barren; withered' (German: 'dürr') \\
\hline [swarx] & $>$ & [svarx] & soarch 'care; conern' (German: 'Sorge') \\
\hline
\end{tabular}

Phonologically, parallel to this change in pronunciation there must have been a change in the syllabic structure, since $n$, as a real consonant, can no longer be a part of the nucleus of the syllable, and consequently, it must have been reallocated to the onset. After velars and dentals, this transition meets no obstacles. Van Coetsem (1951) and Van der Meer (1970) even state that both variants in pronunciation count as one phoneme in Frisian. However, after labials there is a serious problem: $\mathrm{n}$ can simply not be pronounced in that position. Visser (1997) formulates an onset filter to block its realization after labials, following Booij (1995), who observed the same restriction in Dutch. ${ }^{9}$ Indeed, in Dutch one can find words like kwaad 'evil', zwart 'black', dwaas 'mad' or twintig 'twenty', but never onset clusters with * $b w$-, $* p w$-, * $m w$-, $* f w$ - or * $v w$-.

Given this state of affairs, Frisians that already master their language stick to the bilabial pronunciation of /w/ after labials. But what are people doing who are not native speakers of Frisian?

\section{Why change in eastern Friesland?}

The change to a palatal pronunciation of / $/$ in raising diphthongs is of a fairly recent date. It was not earlier than the year 1933 that the change was mentioned in the linguistic literature, be it only in passing. In his Friesche dialectgeographie the journalist and dialectologist Jan Jelles Hof (1872-1952) writes:

9 The same restriction is applicable in English. The reason behind the filter seems to be unclear, at least Kager qualifies it in a recent publication as toevallig, so as "accidental" (Kager (2007: 11). Perhaps, perceptional difficulties form the background, as both consonants are labial. 
"In the bog area from Heerenveen to Drachten the pronunciation bjátsje etc. threatens to be normal, at least after $b, f$, $p$ and $w$. The cause is, that in the last few ages many families of peat diggers from Overijssel and Stellingwerf settled in this area, and for a considerable part started speaking Frisian" (Hof 1933: 10) $)^{10}$

Hof will have based himself on the observations he must have made in the twenties. He registered these and many others in two notebooks, which have been published fairly recently by Van der Veen, Versloot and Rypma (2001). From the data it can be drawn that in some six villages to the north east of the small town of Heerenveen the palatalization has been observed.

In fact, in retrospect there exists an even older description of the situation in these areas. It is from Hof himself, in an article from 1949, when he looks back to the years of his youth:

"Between sixty and seventy years ago I came in that area many times [Hof was a son of the skipper of a small cargo ship, SD]. Then, behind Nijbrêge, Gersleat, Tynje, and De Wispel, and also in the moor areas of Beets, amongst the Frisian peat diggers there still lived of those people from Giethoorn, from above the Linde river, etcetera, who kept speaking their own language when they were among each others, but changed in their contacts with Frisians, and then, they mostly bjátten [i.e. 'played'], at least, the youngsters behaved very much so". (Hof 1949: 83) ${ }^{11}$

10 (In Dutch:) In de laagveenstrook nu van Heerenveen tot Drachten dreigt de uitspraak bjátsje enz. de gewone te worden, althans na $b, f, p$ en $w$. De oorzaak is, dat zich tijdens de laatste paar eeuwen steeds vele Overijsselsche of Stellingwerfsche veenarbeiders-families in dit gebied gevestigd heben en voor het grootste deel Friesch zijn gaan spreken".

11 (In Frisian:) Tusken 'e sechtich en sawntich jier lyn hab ik yn dy krite in bulte myn kommen hawn. Dêr wennen doe, efter Nijbrêge, Gersleat, Tynje en de Wispel út en fierders ek yn 'e Beetster feankriten, tusken 'e Fryske turfmakers noch wol fan dy lju út 'e Giethoarn, boppe fan 'e Linde of wit hwer't se krekt weikamen, dy houden ûnder inoarren har eigen tael noch, mar forbrieken har tsjin 'e Friezen, en dan bjátten se almeast, de jongerein fan dat folk hie dat tominsten slim hiem". 
Thus, this situation must have occurred in the years between 1880 and 1890. What we see here, is that speakers of a non-Frisian language tried to speak Frisian, and that they did not master those difficult raising diphthongs with /w/. Then, they replaced $/ \mathrm{w} /$ by $/ \mathrm{j} /$. So, it seems likely that the change in pronunciation started with emigrants trying to speak Frisian.

At this point, for a better understanding of this whole social setting it might be recommendable to depict the geographical and historical circumstances of this emigration. The south of Friesland had vast areas that consisted of peat bog. This peat, when it was dry enough, could be used for cooking and for the heating of houses. In Holland, this has been the standard material for this purpose for many centuries. However, the exploitation of peat bog needed a special technique, and it were especially the inhabitants of areas directly to the south of Friesland that were mastering these particular skills. When they had digged out their own area, they massively came to Friesland to continue their job, at first from about 1750 in the south west, later in the nineteenth century also in the south and south east of the province.

The question can be posed, then, why we do not find any palatalization of the glide in more western regions of the bog peat district. The answer can be quite straightforward: in the south west of Friesland, so to the west of the small town of Heerenveen, we are in a different dialect area. One of the very features of this south western dialect is, that it has no raising diphthongs with a front glide /w/. Here, the corresponding common Frisian diphthongs /wa/ and /wo/ are represented by two short monophthongs (cf. Hof 1933). So, a pronunciation with initial /j/ could not emerge here at all.

But next to this dialectological answer, it could be questioned whether in the more western regions the social conditions for the change would have been strong enough. For getting some linguistic impact on the autochtonous population, the foreign population has to be robust enough. Although it is true that part of the emigrants settled down once all of the peat had been digged, others moved onward to other areas in order to exploit new fields of peat. As long as peat digging went on, their communities could remain intact for the most part, and hence their own language could continue to exist.

This, however, dramatically changed around the year 1900 . There were two factors. The first is that the demand for peat de- 
creased heavily, since Holland went over to coal for heating. And secondly, as far as the demand remained intact, machines replaced the digging by hand. Thus, a sector that once employed thousands and thousands of labourers, collapsed within few years of time. These labourers rapidly assimilated in the existing society: they became small farmers or small businessmen, and the like. An eyewitness (Koopmans 1954: 31) stated that in his youth at the end of the 19th centure almost all of the children in the village of Tsjalbert spoke the dialect of the peat-diggers. Around 1950, only the elder generation kept speaking it. A school report (Boelens and van der Veen 1956) observed that in 1955 only $10 \%$ of the inhabitants of the village used to speak the old dialect, and that parents mostly spoke Frisian to their children. Of the 152 children visiting the local school, only three sticked to "Gieters", as the dialect is mostly dubbed. In fact, the only autochtonous feature that these emigrants left are their family names (as extensively studied in Kroes 1996).

Next to this area in the bog peat district, there was another region where palatalization took place. In some respects, we see here the mirror image of the scenario just sketched. Again, we are in a peat district, but this time it was not bog peat that was digged, but high moor peat, to be found on the higher grounds along the eastern border of the province of Friesland. And in contrast to the bog peat, this kind of peat was digged by Frisian workers, and not by immigrants. The movement of exploitation was also the opposite: now from the north to the south. And so, eventually, these Frisian workers passed the language border, thereby entering an area where a Low Saxon dialect was the home language. The effect was that in the deep south-east of the province a few Frisian language enclaves were established.

As villages near a language border are open for language mixing in general, it stands to reason that such enclaves on foreign ground are even extra sensitive for such influences. Especially after the collapse of peat digging, the populations will have come to be mixed at a higher degree. Here, within the borders of the enclaves and their immediate surroundings, the original, non-Frisian population had become a minority in relation to the flux of Frisian speaking immigrants. One can imagine that the autochtonous inhabitants tried to accomodate to this Frisian majority, and that by learning Frisian they made the same "mistakes" as Hof noted of those Low Saxon children who pronounced boartsje as [bjatsj?] in the bog peat area. 
That such a scenario indeed must have occurred can be destilled from the Taelatlas fan 'e Wâlden, the linguistic atlas of eastern Friesland (Fokkema and Spahr van der Hoek 1967). In gathering data for our inquiry, this atlas has two virtues. One is, that it shows a fairly densed net. The other is that it provides some additional data according the development over the generations, which shows the increase of the new pronunciation. When we filter out the statements for the generation of sixty years and older, we see that only a few villages are left. All these consist of the aforementioned enclaves and a few villages directly lying at the language border. This picture is supported by Hof (1949: 84). He mentions, as far as palatalization outside the bog peat area is concerned, only the enclaves Appelskea and Haulerwyk, and furthermore De Wylp at the language border, which by the way is also a peat village. Boelens (1958) also mentions, apart from De Tynje in the bog peat area, the enclaves Appelsgea and Easterwâlde as villages with only palatalizing subjects.

When we combine all these data, we must conclude that these villages form the hard core of the change at the eastern front. Fokkema and Spahr van der Hoek's inquiry is from 1959. Their subjects of 60 year and older most have learned their language at the end of the 19th century, that is, the change set off at the same time as in the bog peat area. Fokkema and Spahr van der Hoek (1967) also mention some additional evidence according to their eldest subjects that is telling. The one from Ravenswâld was born that village, but both parents were from non-Frisian origin. The same applies to the other subjects. Only one of them had a parent from a Frisian-speaking village.

All in all, we can conclude that the change of the initial glide from $/ \mathrm{w} /$ to $/ \mathrm{j} /$ is the result of language contact. It could emerge because of the fact that foreigners relatively massively turned the Frisian, and thereby did not master the new language fully.

After the change emerged in the contact areas, it rapidly spread over the area where the autochtonous Frisian population was settled (cf. the maps in Boelens 1958 and Fokkema and Spahr van der Hoek 1967). We see that it gained control in the south, where the contact areas were situated, but that there was also a rapid spread in a northern direction along the language border. Nowadays, there is also a tendency towards areas outside eastern Friesland (cf. Kiers-Bevaart 2006). 


\section{The change as shift}

The change, as we have seen, got going when non-Frisians rather massively tried to learn the language, and thereby not succeeded in mastering it fully. Due to this imperfect learning, it can be qualified as a case of shift, and in my opinion it is a very nice example of this category of contact-induced change.

At this point, those with some knowledge of the Frisian language situation may raise their eyebrows. For it is rather seldom that speakers of Dutch are willing to learn to speak Frisian actively. Why is it that the people at hand turned so rapidly to the new language? All in all, their communities were relatively robust, so they could have sticked to their native tongue. And above all, they were backed by Dutch, in social terms the majority language in Friesland. However, these speakers did not. We have seen that even in a well-known stronghold like the village of Tsjalbert the assimilation took place in a rapid pace.

As mentioned in the introduction, factors like power and prestige again come into play here. One is the social level of the people involved. We should not forget that the peat diggers were really lower class people. They were all poor labourers. It is not a coincidence that they lived in the same district that in 1888 was the first to elect a socialist candidate for the Dutch parliament. Here we see a serious difference with other speakers of Dutch in Friesland, which mostly belong to the higher classes (cf. Gorter, Jelsma, Van der Plank and De Vos 1984: 22-46).

The other factor was, that these workers did not speak the Dutch standard language. Coming from regions directly to the south of Friesland, their native tongue was a variety of Low Saxon, and this variety has not a high standing. At a general level, Frisians consider theirselves as speaking a language, and not a dialect. And for some reason, maybe because it is spoken by close neighbours, this particular Low Saxon dialect is valued relatively low. The term that Frisians use for speakers of the dialect is, that they speak krom, which means 'bent, crooked'. Or, as the Frisian-English dictionary of Dykstra (2000) has it in its definition of the phrase krom prate: 'speak the dialect of the Stellingwerf-area in Friesland', and significantly, it adds the label <pejorative> to it.

In conclusion, although this case of shift might look different at first sight, also this contact-induced change in Frisian is guided by 
factors of power and prestige. And if there could be drawn a moral of this story, one could say that in general one should be careful in using such labels as majority and minority. Sometimes, what at first sight looks like a majority can in fact act as a minority. And in such a case, a minority can unexpectedly turn into a majority.

\section{Address:}

Siebren Dyk

Fryske Akademy

P.O. Box 54

8900 AB Ljouwert/Leeuwarden

The Netherlands

E-mail: sdyk@fryske-akademy.nl

\section{References}

Boelens, K. (1958) “Waar mouilleren in het Fries de stijgende tweeklanken?”. In Album Edgar Blancquaert, 152-158. Tongeren.

Boelens, K. and J. v.d. Veen (1956) De taal van het schoolkind in Friesland. Leeuwarden. Fryske Akademy.

Boelens, K. and G. van der Woude (1955) Dialect-atlas van Friesland. Antwerpen: De Sikkel.

Booij, G. (1995) The phonology of Dutch. Oxford: Clarendon Press.

Coetsem, F. van (1951) "Over en naar aanleiding van een Nieuwfriese Anlautwijziging”. Handelingen V der Zuidnederlandse Maatschappij voor Taalen Letterkunde en Geschiedenis, 84-93.

Cohen, A., C. L. Ebeling, K. Fokkema, and A. G. F. van Holk (1972). Fonologie van het Nederlands en het Fries: inleiding tot de moderne klankleer. 's-Gravenhage; Martinus Nijhof.

Dyk, S. (2008) "Mûljearring: in oersjoch". Us Wurk 57, 1-43.

Dykstra, A. (2000). Frysk-Ingelsk wurdboek. Frisian-English dictionary. Ljouwert and Leeuwarden: Afûk and Fryske Akademy.

FAND = Fonologische Atlas van Nederlandse Dialecten [Frisian part not published yet, but available via the Fryske Akademy].

Fokkema, K. (1940) “Over de Friese klinkers”. In Bundel opstellen van oudleerlingen aangeboden aan Prof. Dr. C.G.N. de Vooys, 140-145. Groningen and Batavia: J.B. Wolters,

Fokkema, K. (1966) “The Frisian phonemes /f/, /v/ and /w/". Phonetica 14, 129 137. Also in K. Fokkema (1969) Nei wider kimen, 246-252. Grins:WoltersNoordhoff. 
Fokkema, K. and J.J. Spahr van der Hoek (1967) Taelatlas fan de W?lden. Assen, Van Gorcum.

Gorter, D., G.H. Jelsma, P.H. van der Plank, and K. de Vos(1984) Taal yn Fryslân. Ljouwert, Fryske Akademy.

[Hof, J. J.] (1903) "Nije drankjes fen Jan fen "e Gaestmar. III. It sportfriezendom". Forjit my net, 44-53.

Hof, J. J. (1933) Friesche dialectgeographie. 's-Gravenhage, Martinus Nijhoff.

Hof, J. J. (1949) "Hjoeddeiske lûd- en foarmforoaringen. 4. Bjátsje op “e bjórren”. De Pompebledden 20, 81-85 and 103-106.

Kager, R. (2007) Zoeken naar woorden. Inaugural speech, Universiteit Utrecht.

Kiers-Bevaart, M. (2006) "Rekkendei mei foaroardielen. Mouillearring: sprieding en oardiel". Unpublished master thesis, University of Groningen.

Kroes, J. (1996) De Gietersen in Friesland. De migratie van NoordwestOverijsselse turfgravers naar het Friese laagveengebied in de tweede helft van de 18e eeuw. Ljouwert and Leeuwarden: Fryske Akademy.

Koopmans, A. F. (1954) "Ynvaezje fan 'Gietersk' turfmakkersfolk nei de omkriten fan it Hearrenfean". It Beaken 16, 27-31.

Meer, G. van der (1970) “Toppenhúster konsonantyske bigjingroepen”. Us Wurk $19,39-43$.

Meer, G. van der (1985) Frisian 'Breaking'. Aspects of the origin and development of a sound change. [Dissertation Rijksuniversiteit Groningen.]Grins and Groningen: Stifting FFYRUG.

Siebs, Th. (1901) “Geschichte der friesischen Sprache”. In H. Paul, ed. Grundriss der germanischen Philologie. I . Strassburg, Karl J. Trübner.

Thomason, S.G. and T. Kaufman (1988) Language contact, creolization, and genetic linguistics. Berkeley: University of California Press.

Veen, K.F. van der, A. Versloot, and W. Rypma (2001) Dialektgeografyske oantekens fan J.J. Hof. Ljouwert: Fryske Akademy.

Visser, W. (1997) The syllable in Frisian. [Dissertation Vrije Universiteit.] The Hague: Holland Academic Graphics.

Kokkuvõte. Siebren Dyk: Siirdehääliku palatalisatsioon friisi kee-
le tõusvates diftongides kui märk häälduskoha nihkest. Tänapäeva läänefriisi keeles on arenenud kaks tõusvat diftongi, mille algusesse hääldatakse /w/. Idapoolsetel aladel hääldatakse selliseid järjestusi [jo] ja [ja]na. Muutus sai alguse siis, kui immigrantidest turbakaevurid integreerusid Friisi ühiskonda ja ei omandanud puuduliku õppe tõttu keeruliste friisi diftongide hääldust täielikult. Nad hääldasid diftongialgulist siirdehäälikut eespoolselt, s.o /j/-na. Teine muutusekeskus oli piirialadel, kus rahvastik segunes samuti turbakaevamise tulemusel. 20. sajandil levisid uued 
vormid kiiresti. Häälduskoha nihkumine (nt Thomason ja Kaufman 1988) seletab hästi siirdehääliku palatalisatsiooni. Veelgi enam, see annab ülevaate ka sellest, miks niisugune nähtus ilmneb ainult labiaalide järel. Vähemuse ja enamuse kontakti puhul ei eeldata siiski seda, et muutus toimub vähemuskeeles, kuna see nõuab, et rahvastik lülituks ümber sihtrühma keelele, millel on vähem võimu ja prestiiži. Ometi rääkisid kõik turbakaevurid hollandi keele alamsaksi murret, millel oli tõepoolest madal prestiiž.

Märksõnad: friisi keel, murdumine, palatalisatsioon, keelemuutus, keele prestiiž 
